ISSN 0258-7122

Bangladesh J. Agril. Res. 36(4): 575-582, December 2011

\title{
ON - FARM EVALUATION OF NATURAL TOXICANTS FROM TEPHROSIA VOGELII AND PETIVERIA ALLIACEA ON MEGALUROTHRIPS SJOSTEDTI AND APION VARIUM OF COWPEA (Vigna Unguiculata (L) WALP)
}

\author{
F. O. AlaO ${ }^{1}$, T. A. Adebayo ${ }^{2}$ and O. A. Olaniran ${ }^{3}$
}

\begin{abstract}
The field study was conducted during the planting season of cowpea to evaluate the natural toxicant from Tephrosia vogelii and Petiveria alliacea and their mixture against Megalurothrips sjostedti and Apion varium at three different concentrations $(5,10$, and $20 \% \mathrm{v} / \mathrm{v})$. The experiment was set up in randomized complete block design. The field observations showed that the two insect pests were effectively controlled by the botanical insecticides compared with untreated plants. Also, the plant extracts at $20 \%$ and $10 \% \mathrm{v} / \mathrm{v}$ significantly protected cowpea pods and grains from the damage. However, higher grain yield was obtained from the plant treated with $20 \% \mathrm{v} / \mathrm{v}$ compared to those treated with $10 \%, 5 \% \mathrm{v} / \mathrm{v}$ and untreated plants. Combination of the two plant extracts at $20 \%$ $\mathrm{v} / \mathrm{v}$ had the same efficacy with synthetic insecticide (Decis). Thus, these plant extracts can be used in organic farming.
\end{abstract}

Keywords: Megalurothrips sjostedti, Apion varium, Tephrosia vogelii, Petiveria alliacea, concentrations.

\section{Introduction}

Cowpea is an important crop for farmers in most of the West African countries, where Nigeria and Niger account for $87 \%$ of world cowpea harvested (Ortiz, 1998). It is one of the most important protein sources in the diet of Tropical Africa. Despite its importance, the production is yet to meet the demand of consumers due to the low yields being experienced by the farmers (Karungi et al., 2000). Insect pests have been reported to have caused economic damage to the crop (Ajeigbe and Singh, 2006; and Karungi et al., 2000). However, the following insect pests have been reported to have caused approximately $70 \%$ yield loss: bud thrips (Megalurothrips sjostedti trybom), pod borer (Maruca vitrata Fabricius) and pod sucking bugs, such as Clavigralla tomentoscollis Stal; Riptortus dentipes Fabricius; Anoplcnemis Curvipes Fabricius and Nezara viridula Linnaeus.

Since pests constitute the main limiting factors in the production of cowpea, the quickest and most pragmatic way of controlling these pests is the use of conventional insecticide (Adebayo and Olaifa, 2004). However, synthetic insecticides have been reported to have some side effects, such as high

${ }^{1,2 \& 3}$ Department of Agronomy, Ladoke Akintola University of Technology, Ogbomoso, Nigeria. 
mammalian toxicity, environmental pollution, insect resistance and resurgence, high cost and unavailability at critical periods (Duke, 1997). Those aforementioned problems have stimulated interest of pest-management specialists in developing alternatives pest control in recent years.

Plant-based insecticides have been reported as a better option to synthetic insecticide (Isman, 2008). Environmental and ecological suitability of botanical insecticide enhance its acceptability among the entomologists as a sustainable alternative to the conventional insecticide. In Nigeria, there are several insecticidal plants; among these, Tephrosia vogelii which contains Rotenone as the active ingredient and has been reported to be useful against most of the sucking and bitting insects (McDavide and Lesseps, 1995 and Stoll, 2001). However, Petiveria alliacea contains Dibenzyltrisulfide, which is the active insecticidal compound (Lyndon et al., 1997; Kubec and Musah, 2000 and Kubec et al., 2002).

Developing alternative option to synthetic insecticide from plants, especially in developing countries like Nigeria will go a long way in alleviating the poverty level of farmers and put to rest problem of low productivity due to insects attack. Also, protection of consumers from taking pesticides contaminated food stuffs will be realized (Adebayo and Olaifa, 2004). Therefore, the present study aimed at evaluating the natural toxicant from the two plants against the two major destructive insect pests of cowpea and to determine whether the plant extracts can be a substitute to synthetic insecticide (Decis) in controlling the major pests of cowpea.

\section{Materials and Method}

The field experiment was conducted at Ladoke Akintola University of Technology (LAUTECH) Teaching and Research Farm, Ogbomoso, Oyo State. Ogbomoso is located on longitude $4^{\circ} 30^{\circ} \mathrm{E}$ and Latitude $10^{0} 5^{1} \mathrm{~N}$. The climate could be described as hot humid tropical falls in Southern Guinea Savanna of Nigeria with a mean temperature of $27^{\circ} \mathrm{C}$, annual rainfall of $1400 \mathrm{~mm}$ and marked with dry and wet seasons.

The experimental site was 0.06 hectare of land, which was ploughed and harrowed once. Thirty three plots were demarcated and arranged in a randomized complete block design with three replications of twelve treatment combinations. Each plot had five rows. The plot size was $3 \mathrm{~m} \times 3 \mathrm{~m}$ with $1 \mathrm{~m} \times 2 \mathrm{~m}$ gaps between adjacent plots and blocks.

The cowpea variety was Ife brown. Planting was done in 2007 cropping season, two to three seeds were sown per stand and thinning was done one week after planting to achieve one plant per stand. The crop was spaced out at $30 \mathrm{~cm} \mathrm{x}$ $60 \mathrm{~cm}$. Two weeks after planting, all the plants were treated with synthetic 
insecticide to prevent pre-flowering insects attack. The plant materials used were collected from botanical garden LAUTECH.

Five hundred grammes (500g) each of fresh leaves of $T$. vogelli and root of $P$ alliacea were crushed separately and applied at concentrations of 5, 10, and 20\% $\mathrm{v} / \mathrm{v}$, while $20 \mathrm{ml} / \mathrm{ha}$ was applied as synthetic insecticide. However, each of the concentration was further diluted with 1 litre of water before the application. Thereafter, applications which commenced 35 days after planting were made weekly over a 4-week period giving a total of four applications. This was done in the early hours of the day to avoid photo decompositi on of the plant extracts.

Population densities of nymph of $M$. sjostedti was measured by random picking of 5 flowers per plot at 50\% flowering stage. The flowers were placed in a glass vials containing 30\% alcohol. After dissection, the flowers were opened and the insects found were counted and recorded. Apion varium was sampled after each weekly spraying.

At full ripening (65 days) stage, 30 pods were picked randomly from the middle row in each plot. The pods were observed and rated for pod damaged by twisting, stunting, infested, constricting, and shriveling and were used as a measure to determine pod damage. The grain yield was determined per hectare. Hundred grains were picked randomly from extracted seeds. Wrinkle and grains showing feeding punctures from 100 grains were used to rate grain quality (Oparaeke, 2005)

Data collected were subjected to analysis of variance (ANOVA) using RCB design as explained by Gomez and Gomez (1987) significant means were compared using Ducans multiple range test (DMRT) at 5\% probability level.

\section{Results}

\section{Efficacy of plant extracts on populations of Megalurothrips sjostedti}

Table 1 shows a general decreasing trend of $M$. sjostedti. The highest mean populations of this insect were recorded from unsprayed plots and plots treated with $T$. vogelii at $5 \%$ concentrations were ranked next to it at all the weeks of treatment. However, the least mean population was observed from plots treated with Decis.

Among the plant extracts, highest mean populations of $M$. sjostedti were observed from plots treated with plant extracts at 5\% concentrations with significant high populations at $1^{\text {st }}$ and $2^{\text {nd }}$ week. Also, no significant differences of population was observed from plots treated with $20 \% \mathrm{v} / \mathrm{v}$ plant extracts either singly or as a mixture. However, at $3^{\text {rd }}$ and $4^{\text {th }}$ week, the application of plant extracts at $20 \% \mathrm{v} / \mathrm{v}$ either singly or as a mixture caused significant reduction of M. sjostedti as exhibited by Decis. All plant extracts irrespective of the concentrations were significantly effective than the unsprayed plots. 
Table 1. Mean number of $M$. sjostedti in response to weekly application of plant extracts.

\begin{tabular}{|c|c|c|c|c|}
\hline \multirow{2}{*}{ Treatment } & \multicolumn{4}{|c|}{ Weeks after treatment } \\
\hline & 1 & 2 & 3 & 4 \\
\hline Control & $38.0 \mathrm{a}$ & $32.6 a$ & $30.7 a$ & $16.0 \mathrm{a}$ \\
\hline Decis & $2.67 d$ & 2.33e & $0.00 \mathrm{e}$ & $0.00 \mathrm{~d}$ \\
\hline T.v (5\%) & $32.7 \mathrm{a}$ & 27.3ab & $17.7 b$ & $10.0 \mathrm{~b}$ \\
\hline T.v (10\%) & 13.0bcd & 11.3cde & $9.67 \mathrm{bc}$ & $6.33 \mathrm{bc}$ \\
\hline T.v (20\%) & $13.0 \mathrm{bcd}$ & 7.33cde & 4.33 de & $0.33 d$ \\
\hline P.a (5\%) & $22.0 \mathrm{a}$ & 20.0cde & $8.33 \mathrm{dc}$ & $6.67 \mathrm{bc}$ \\
\hline P.a (10\%) & $14.3 \mathrm{bc}$ & 11.6cde & 8.33cd & $5.67 \mathrm{bc}$ \\
\hline P.a (20\%) & 13.0bcd & $6.33 \mathrm{~d} \mathrm{e}$ & 4.67de & $0.33 d$ \\
\hline $\mathrm{T} . \mathrm{v}+\mathrm{Pa}(5 \%)$ & $21.7 \mathrm{~b}$ & 16.3bcd & $12.7 \mathrm{bc}$ & $7.00 \mathrm{bc}$ \\
\hline $\mathrm{T} . \mathrm{v}+\mathrm{Pa}(10 \%)$ & 12.3bcd & 9.33cde & 5.00de & $2.67 \mathrm{~cd}$ \\
\hline T.v+Pa (20\%) & 12.3bcd & 6.00de & 3.67de & $0.33 d$ \\
\hline
\end{tabular}

T.v = Tephrosia vogelii

P.a $=$ Petiveria alliace

Mean having the same alphabet (s) in a column are not significantly different $(\mathrm{p}<0.05$ test)

\section{Efficacy of plant extracts on populations of Apion varium}

The population of $A$. varium decreased as the number of treatments increased although the same trend was not observed in the unsprayed plots. Also, plots treated with $P$. alliacea at $10 \% \mathrm{v} / \mathrm{v}$ had the highest mean population $(0.78)$ at ${ }_{2}$ nd week compared with mean population recorded as $1^{\text {st }}$ week after treatment $(0.67)$. At $2^{\text {nd }}$ and $3^{\text {rd }}$ week, no significant differences were observed among plant extracts-treated plots (Table 2)

Throughout the four weeks of treatment, plots treated with plant extracts caused significant reduction of $A$. varium than the unsprayed plots. However, at the $4^{\text {th }}$ week, the application of plant extracts at $20 \%$ concentrations significantly controlled this insect in the same way as Decis. The application of Decis and combination of two extracts at $20 \%$ concentrations at $3^{\text {rd }}$ and $4^{\text {th }}$ week indicated the efficacy of the two treatments in repelling the $A$. varium owing to absence of the insect in the plots. Also, the insect was not observed in the plots treated with T. vogelii, $P$. alliacea at $20 \%$ concentrations and combination of the two extracts at $10 \%$ concentrations at $4^{\text {th }}$ week (Table 2 ). It was observed that the efficacy of the combination of the two plant extracts at $10 \% \mathrm{v} / \mathrm{v}$ was comparable with the single application at $20 \%$ concentrations. 
Table 2. Mean number of $A$. varium in response to weekly application of plant extracts.

\begin{tabular}{l|l|l|l|l}
\hline \multirow{2}{*}{ Treatment } & \multicolumn{5}{c}{ Weeks after treatment } \\
\cline { 2 - 5 } & 1 & 2 & 3 & 4 \\
\hline Control & $2.00 \mathrm{a}$ & $2.22 \mathrm{a}$ & $1.67 \mathrm{a}$ & $1.22 \mathrm{a}$ \\
Decis & $0.22 \mathrm{bc}$ & $0.1 \mathrm{lb}$ & $0.00 \mathrm{~b}$ & $0.00 \mathrm{c}$ \\
T.v (5\%) & $0.67 \mathrm{c}$ & $0.67 \mathrm{~b}$ & $0.56 \mathrm{~b}$ & $0.45 \mathrm{bc}$ \\
T.v (10\%) & $1.1 \mathrm{lb}$ & $0.44 \mathrm{~b}$ & $0.78 \mathrm{~b}$ & $0.22 \mathrm{bc}$ \\
T.v (20\%) & $0.22 \mathrm{~b}$ & $0.22 \mathrm{~b}$ & $0.22 \mathrm{~b}$ & $0.00 \mathrm{c}$ \\
P.a (5\%) & $1.1 \mathrm{lb}$ & $1.00 \mathrm{~b}$ & $0.78 \mathrm{~b}$ & $0.68 \mathrm{ca}$ \\
P.a (10\%) & $0.67 \mathrm{bc}$ & $0.78 \mathrm{~b}$ & $0.67 \mathrm{~b}$ & $0.44 \mathrm{bc}$ \\
P.a (s20\%) & $0.45 \mathrm{bc}$ & $0.33 \mathrm{~b}$ & $0.33 \mathrm{~b}$ & $0.11 \mathrm{bc}$ \\
T.v+Pa (5\%) & $0.78 \mathrm{bc}$ & $0.45 \mathrm{~b}$ & $0.22 \mathrm{~b}$ & $0.22 \mathrm{c}$ \\
T.v+Pa (10\%) & $0.56 \mathrm{bc}$ & $0.22 \mathrm{~b}$ & $0.11 \mathrm{~b}$ & $0.00 \mathrm{c}$ \\
T.v+Pa (20\%) & $0.45 \mathrm{bc}$ & $0.1 \mathrm{lb}$ & $0.00 \mathrm{~b}$ & $0.00 \mathrm{c}$ \\
\hline
\end{tabular}

Mean having the same alphabet (s) in a column are not significantly different $(\mathrm{p}<0.05$ test)

Table 3. Grain yield, pod damage and grain quality of cowpea after application of the plant extracts.

\begin{tabular}{lcccc}
\hline \multicolumn{1}{c}{ Treatments } & Yield (kg/ha) & Pod damage (\%) & Grain quality (\%) \\
\hline Control & 1591 & $93 \mathrm{a}$ & $15 \mathrm{f}$ \\
Decis & $967 \mathrm{a}$ & lof & $96 \mathrm{a}$ \\
T. vogelli 5\% & $162 \mathrm{gh}$ & $80 \mathrm{ab}$ & $19 \mathrm{ef}$ \\
T. vogelli 10\% & $459 \mathrm{e}$ & $33 \mathrm{~d}$ & $47 \mathrm{c}$ \\
T. vogelli 20\% & $616 \mathrm{c}$ & $23 \mathrm{ef}$ & $71 \mathrm{~b}$ \\
P. allicea 5\% & $214 \mathrm{~g}$ & $73 \mathrm{~b}$ & $26 \mathrm{ed}$ \\
P. allicea 10\% & $441 \mathrm{e}$ & $36 \mathrm{~cd}$ & $43 \mathrm{c}$ \\
P. allicea 20\% & $600 \mathrm{c}$ & $37 \mathrm{ef}$ & $69 \mathrm{~b}$ \\
Tv + P.a 5\% & 326f & $43 \mathrm{c}$ & $31 \mathrm{~d}$ \\
Tv + P. a 10\% & 526d & $23 \mathrm{ef}$ & $61 \mathrm{~b}$ \\
Tv + P.a 20\% & $766 \mathrm{c}$ & $17 \mathrm{f}$ & $87 \mathrm{a}$ \\
\hline
\end{tabular}

Mean having the same alphabet (s) in a column are not significantly different $(\mathrm{p}<0.05$ test)

With reference to yield parameters, all the extract-treated plots were significantly effective than unsprayed plots with the least yield of $159 \mathrm{~kg} / \mathrm{ha}$. 
Higher yield of $967 \mathrm{~kg} / \mathrm{ha}$ was recorded from Decis-treated plots, which was almost closely followed by the combination of two plant extracts at $20 \% \mathrm{v} / \mathrm{v}$ (767 $\mathrm{kg} / \mathrm{ha}$ ) (Table 3). Ninety three percent pods were damaged by A. varium in the unsprayed plots. Pods were effectively protected with extract applied at $20 \% \mathrm{v} / \mathrm{v}$. However, the botanical treatments protected grains from infestation than the unsprayed plants.

\section{Discussion}

Attempt was made to investigate the natural toxicant from two plant extracts $-\mathrm{T}$. vogelli and $P$. alliacea and their synergistic effects at three tested concentrations (5, 10 , and $20 \% \mathrm{v} / \mathrm{v})$ in the suppressing $M$. sjostedti and $A$. varium. In this study, the plant extracts applied singly at $20 \% \mathrm{v} / \mathrm{v}$ had $80 \%$ reduction of the target pests but extracts applied at $5 \% \mathrm{v} / \mathrm{v}$ had least efficacy ranging from $31-45 \%$. This indicated that the application of these plant extracts at $20 \% \mathrm{v} / \mathrm{v}$ were sufficient to bring the target insects below economically critical infestation threshold level. This work agrees with Adipala et al. (2005) who reported that plant extracts effectively controlled pod-sucking insects.

Interestingly, combination of these two extracts at $20 \% \mathrm{v} / \mathrm{v}$ was significantly effective as synthetic insecticide (Decis) in controlling the target insects and combination of the two extracts at $10 \% \mathrm{v} / \mathrm{v}$ had equal efficacy $(80 \%)$ with single application at $20 \% \mathrm{v} / \mathrm{v}$ against the target insects. This agrees with earlier report made by Adebayo, 2003 who observed that formulation of $T$. vogelii with locust lotion was effective as Lambda-cyalothrin in controlling insect pests of cowpea.

The data also suggest that there was an increased repellent activity with increasing concentrations of the plant extracts against target insect pests of cowpea indicating that the active ingredients derived from these two plants were active at a very high concentration and probably demonstrated why less number of pods were damaged, from plots treated with $20 \%$ concentrations followed by $10 \% \mathrm{v} / \mathrm{v}$, while $5 \% \mathrm{v} / \mathrm{v}$ extract treated plots had nearly equal number of pods damaged as recorded from unsprayed plots. Therefore, the effectiveness of the two active ingredients as insecticides depend on dosage applied. This agrees with Seljasen and Meadow (2006) who reported that effectiveness of neem as insecticide was dose-dependent.

The final yield in any crop is determined by many factors both environmental and physiological factors, and damage by insects has reported by Adebayo, 2003 is an integral component of the two factors, this accounted for the reason why the plots not treated with insecticides had the highest number of insects population and hence the least number of yield.

Matsmura (1985) reported that among six roteniods which occur naturally from $T$. vogelii, rotenone was found to be the most insecticidal which can act as 
either a contact or stomach poison, while Dibenzyltrisulfide, an insecticidal compound isolated from P. alliacea, acts as repellant (Mansingh and Williams 1998). This was probably why pods and grains from the unsprayed plants were severely damaged compared to the plant extracts treated plants. However, Rotenone and Dibenzyltrisulfide reportedly derived from $T$. vogelii and $P$. alliance, respectively, exhibited slow activity in the first two weeks after treatment against the target insect pests compared to synthetic insecticide suggesting the repellant activity of the two active ingredients. Delayed effect is one of the major problems of botanical insecticides (Isman, 2008). Ajeigbe and Singh (2006) observed that synthetic insecticide has quick effect on insect pests of cowpea compared to plant-derived insecticide.

\section{References}

Adebayo T. A. 2003. Efficacy of mixture formulations of synthetic and botanical insecticides in the control of insect pests of Okra and cowpea, Ph.D thesis, Ladoke Akintola University of Technology, Ogbomoso, Nigeria.

Adebayo, T. A. and J.I. Olaifa. 2004. Efficiency of the extract of Tephrosia vogelii in the control of inset pests of cowpea. Science focus 7: 47-52.

Adipala, E., R.S. Kawuki, A. Agona and P. Nampala. 2005. A comparison of effectiveness of plant-based and synthetic insecticides in the field management of pod and storage pests of cowpea. Crop Prot. 24: 473-478.

Ajaigbe, H.A. and B.B. Singh. 2006. Integrated pest management in cowpea: Effect of time and frequency of insecticide application on productivity. Crop Prot. 25: 920-925

Duke, S.O. 1997. Natural pesticides from plants. Janick Timber Press, Portland, Hilton.

Gomez, K.A. and A.A. Gomez. 1987. Statistical Procedures for Agriculture Research. $2^{\text {nd }}$ Ed., Willey Interscience, New York. pp. 680

Isman, M.B. 2008. Botanical Insecticides: For richer, for poorer. Pest Manag. Sci. 64: 8-11.

Karungi, J., E.J. Adipala, S. Kyamanyawa, M.W. Ogenga-Latigo, N. Oyobo, and L.E.N. Jackai. 2000. Pest Management in Cowpea. Part 2. Integrating planting time, plant density and insecticide application for management of cowpea field insect pest in eastern Uganda. Crop Prot. 19: 237-245.

Kubec, R. and R.A. Musah. 2000. Cysteinesulfoxide derivatives in Petiveria alliacea. Phytochemisry 58: 981-985.

Kubec, R., S. Kim and R.S. Musah. 2002. S-substituted cysteine derivatives and thiosulfinate formation in and thiosulfinate formation in Petiveria alliacea part II. Phytochemistry 61: 675-680.

Lyndon, J., W. Lawrence and V. R. Earle. 1997. An insecticidal and acaricidal polysulfide metabolite from the roots of Petiveria alliacea. Pest Sci. 50: 228-232.

Mansingh, A. and L.A.D Williams. 1998. Pesticides of tropical plants II Acaricidal activity of crude extracts of several Jamacia plants. Insect Sci. Appli. 18 (21): 149- 155. 
Matsumura, F. 1985. Toxicology of insecticides. $2^{\text {nd }}$ Ed. Plenum Publishing Corporation, New York. pp 598

McDavide, A. and R.S.J. Lesseps. 1995. Natural plants as pesticides. In: Proceedings from the first National Symposium, 2-5 August 1995, Lutsaka, Zambia. pp. 135-147.

Oparaeke, A., M. 2005. Studies on insecticidal potential of extracts of Gmelina arborea products for control of field pests of cowpea (Vigna unguiculata (L) Walp): The pod borer, Maruca vitrata and the Coreid bug, Clavigralla tomentosicollis. Journal of Plant Protection Research 45:1-7.

Ortiz, R.1998. Cowpea from Nigeria: A salient food revolution. Outlook on Agriculture 27(2): 125-128.

Seljasen, R. and R. Meadow. 2006. Effects of neem on oviposition and egg and larvae development of mamestra Brassicae L: Dose response, residual activity, repellent effect and systemic activity in cabbage plants. Crop Prot. 25: 338 - 345.

Stoll, G. 2002. Natural crop protection in the tropics. Letting information come to life. F and T. Millerbader fildstadt polishers, Germany. pp.208. 